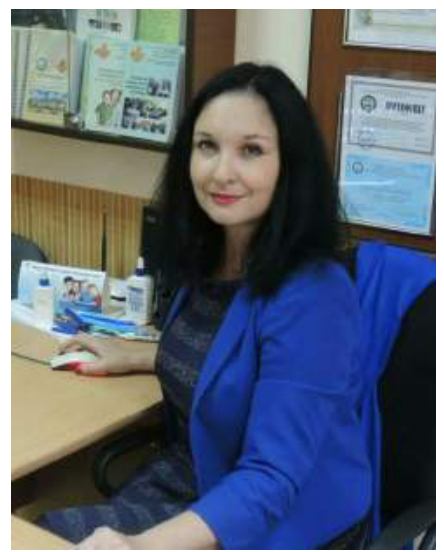

\author{
Тетяна Данилюк, \\ аспірант, \\ ДВНЗ «Прикарпатський національний \\ університет імені Василя Стефаника» \\ (м. Івано-Франківськ, Україна)
}

\author{
Tatyana Danilyuk, \\ postgraduate student, \\ Vasyl Stefanyk Precarpathian National University \\ (Ivano-Frankivsk, Ukraine) \\ tet_danilyuk@ukr.net
}

\title{
ЛІТЕРАТУРНЕ КРАЄЗНАВСТВО ЯК ПРОВІДНА ЗАСАДА СУЧАСНОЇ ШКОЛИ
}

Анотація. Літературне краєзнавство - це важливий чинник патріотичного, морально-етичного виховання, дійовий засіб поглиблення знань з літератури і розвитку пізнавальних інтересів молодших школярів. Воно сприяє вихованню національної самосвідомості, зацікавленню учнів історією, культурою рідного краю, його фольклорними традиціями, формує духовний світ особистості, виховує загальнолюдські й національні цінності в молодших школярів.

Ключові слова: краєзнавство, літературне краєзнавство, література рідного краю, молодший школяр.

\section{LITERARY REGIONAL ETHNOGRAPHY AS A GUIDELINE OF MODERN SCHOOL}

Abstract. Literary regional ethnography is an important factor of patriotic, moral and ethical upbringing, an effective means of improving knowledge of literature and developing cognitive interests of junior pupils. It promotes upbringing of national consciousness, students' interest in the history and culture of the native land, its folk traditions, forms the spiritual world of the personality, cultivates junior pupils' human and national values. The task of the lessons of literature of the native land is to deepen the information about life and work of artists of a certain area (in our case, Precarpathia); to develop interest in their creative work and heritage; to form children's historical memory; to instill respect for the outstanding people of their native land, the ircontribution to the national liberation struggle, to encourage junior pupils to imitate them in their lives; to cultivate hard work, charity, humane attitude towards person, nature, etc.

Keywords: regional studies, literary regional studies, native land literature, lesson of literary reading.

\section{ВСТУП}

Постановка проблеми. Українська література на сучасному етапі розбудови нашої держави усвідомлюється як чинник національного відродження. Тому необхідно враховувати визначальну роль особистості в суспільному житті країни, яка творить і зберігає історію, відроджує національну культуру, духовність, літературу, мову. Отож важливим складником національно-мовної особистості виступає ціннісний, світоглядний, культурологічний, пізнавальний, поведінковий та інші компоненти, мовна, інтелектуальна здібність, мовне чуття [1, с. 3; 8, с. 4-7]. У цій складній системі літературне краєзнавство посідає чільне місце.

За сучасних умов літературне краєзнавство $є$ важливою державною справою, коли йому належать відповідальні фрункції в освітньому процесі - відродження духовності, формування національної самосвідомості, національнопатріотичних цінностей у школярів, виховання літературознавчої компетентності, любові до читання тощо. Відповідно оновлюються методи організації навчальної роботи, а також удосконалюються форми вивчення літератури рідного краю в загальноосвітніх навчальних закладах. Чим глибші й змістовніші будуть знання учнів про рідний край, Батьківщину, видатних людей, тим більше буде можливості для фрормування загальнолюдських та національно-патріотичних почуттів школярів. Саме уроки літературного краєзнавства дають можливість ознайомити учнів із цікавими прозовими текстами про рідний край, донести до дітей поетичні рядки, сповнені красою карпатського краю, звернутися до народної та духовної спадщини Прикарпаття. Вивчати твори письменників-земляків корисно й цікаво, оскільки вони приваблюють читачів і різноманітністю тематики, і стилем, і художніми засобами, і широким жанровим діапазоном.

Актуальність проблеми національного виховання визначається вимогами до становлення та розвитку національно-мовної особистості і громадянина Української держави. Головна мета національного виховання набуття молодим поколінням соціального досвіду, успадкування духовних надбань українського народу, досягнення високої культури міжнаціональних взаємин, формування в дітей та юнацтва особистісних рис громадян української держави, розвиненої духовності, моральної, художньо-естетичної культури тощо [4]. Концепція патріотичного виховання орієнтує вчителів початкової школи на усвідомлення важливих цілей і завдань гуманітаризації освіти: щоб виховати національно-свідому, духовно багату мовну особистість, слід формувати у школярів соціокультурні знання й уміння. 3-поміж пріоритетних напрямів державної політики визначено «розширення україномовного освітнього простору», «збереження та збагачення українських культурно-історичних традицій, виховання шанобливого ставлення до національних святинь, української мови» [4]

Тому так важливо в молодшому шкільному віці формувати здатність дитини пізнавати себе як члена сім'ї, родини, як учня, мешканця міста чи села; виховувати любов до рідного дому, краю, вулиці, своєї країни, її 
природи, рідного слова, традицій та ін. У початкових класах особливої значущості набуває проблема використання краєзнавчого матеріалу як засобу вдосконалення навчально-виховного процесу.

Аналіз шкільної практики засвідчує наявність суперечностей між завданнями, що передбачені навчальною програмою початкової школи, та недостатньо розробленим методичним фондом використання літературного краєзнавства. Зняття цих суперечностей передбачає організацію цілеспрямованої системи роботи щодо формування молодшого школяра як національно-мовної особистості засобами літератури рідного краю.

Аналіз останніх досліджень і публікацій. Біля витоків вивчення педагогічних засад літературного краєзнавства стояли видатні українські науковці та культурно-освітні діячі. Значний внесок у визначення сутності, мети, завдань і змісту національного виховання зробили знані педагоги минулого: Г. Ващенко, О. Духнович, С. Русова, К. Ушинський, Я.Чепіга та інші. Сучасний етап розвитку системи мовної освіти характеризується прагненням науковців (А. Богуш, М. Вашуленко, О. Вашуленко, О. Горошкіна, О. Коломінова, В. Кононенко, Ю. Кузьменко, Л. Мацько, К. Пономарьова, О. Савченко, О. Семеног та ін.) визначити мету фрормування соціокультурної компетентності, її складники, зміст, методи, прийоми і засоби, які забезпечують громадянське, патріотичне, морально-етичне, естетичне виховання, низку вмінь і навичок, необхідних для загальнокультурного розвитку учнів, адаптації їх до життя в певному соціальному середовищі. Деякі аспекти використання літературного краєзнавства в початковій школі висвітлено в педагогічних дослідженнях Т. Бондаренко, В. Бугрія, В. Войтової, В. Обозного, В. Романька, Н. Рудницької, М. Солов'я та в працях науковців-методистів Л. Башманівської, І. Волинець, М. Гордої, Л. Іванової, А. Лисенко, О. Лисенко та ін. Окремі напрями шкільного літературного краєзнавства були предметом розгляду в дисертаціях Ю. Верольського, І. Волинець, А. Лисенко, В. Лящук, Т. Посадковської, Л. Прокоф’євої, Л. Скепнера, О. Фесенко та ін. Однак порушена в назві статті наукова проблема широко вченими не розглядалася.

META I ЗАВДАННЯ ДОсЛІДЖЕННЯ полягають в аналізі теорії і практики виховання національно-мовної особистості молодшого школяра засобами літературного краєзнавства.

МЕТОДИ ДОслІДЖЕНнЯ: аналіз державних документів з проблем освіти та виховання дітей і молоді, навчальних планів напряму підготовки «Початкова освіта»; аналіз та узагальнення психолого-педагогічної та науково-методичної літератури з проблеми; визначення теоретико-методичних засад дослідження.

\section{РЕЗУЛЬТАТИ ДОСЛІДЖЕННЯ}

У сучасних педагогічних, методичних та лінгвістичних дослідженнях та концепціях [1-10], що порушують питання виховання особистості засобами рідного слова та мови, використовуються поняття «мовно-національне виховання», «мовне виховання особистості», «рідномовне виховання», «виховання мовної особистості»,

«виховання культуромовної особистості» тощо. Отже, за сучасних умов розвитку української державності, відродження національної культури та освіти одним з головних завдань, що входять до програми реформування змісту навчання і виховання, є національно-мовне виховання особистості.

На це орієнтують і основні освітні документи. Так, у «Концепції національно-патріотичного виховання дітей і молоді» підкреслюється, що одним із основних завдань виховання є «розвиток почуття любові до Батьківщини і свого народу як основи духовного розвитку особистості, шанобливе ставлення до історичних пам'яток, активна діяльність школярів по поліпшенню умов життя в рідній місцевості, підвищенню матеріального і духовного рівнів життя народу, дійова участь у розбудові держави й духовному оновленні суспільства» [4].

Знання про рідний край необхідні для духовного розвитку дитини, як уміння читати і писати. Вивчення місцевої літератури, фольклору тощо сприяє формуванню в дітей національної свідомості та гідності, духовності. Проте, на жаль, література рідного краю, попри акцентування уваги на її ролі в національному вихованні молодших школярів, часто залишається відстороненою від навчально-виховного процесу в загальноосвітній школі I-ІІ ступенів.

Українознавчі підходи до мовної освіти, на думку авторитетного науковця В. Шляхової, «забезпечуються текстоцентризмом, тобто, у багатофункціональному використанні українознавчих текстів» [10]. Тому важливо добирати такий дидактичний матеріал, який зможе вплинути на емоційний стан учнів, викликати в них бажання висловитися - поділитися враженнями, переживаннями; здатний виховати любов до Батьківщини, рідної мови; стимулювати мовленнєву діяльність; активізувати процеси використання української мови, посилювати її комунікаційний потенціал, тощо. Отже, регіональний краєзнавчий компонент українознавчої змістової лінії поглиблюватиме зв'язок життя з навчанням. Оволодіння літературним краєзнавством у початкових класах сприяє входженню молодших школярів у життя, родинний і громадський побут, літературну й культурну ссреру рідного етносу. Цей процес потребує визначення критеріїв формування змісту літературного краєзнавства, пріоритетних напрямів, шляхів та концептуальнометодичних засад розробки чіткої системи інноваційних форм, методів, прийомів та засобів навчання.

Виходячи з розуміння літературного краєзнавства як специфічної галузі науки про літературу, предметом якої $€$ комплексне вивчення літературних творів, персоналій письменників, літературних образів, традицій, фрольклору та інших художніх елементів та специфічних особливостей прямо чи опосередковано пов'язаних з рідним краєм [3], можна зробити висновок і про недостатню розробленість проблеми використання літературного краєзнавства в системі підготовки вчителів початкових класів та необхідність її ґрунтовного вивчення.

Так, аналіз навчальних планів напряму підготовки «Початкова освіта» ДВНЗ «Прикарпатський національний університет імені Василя Стефраника» дає підстави стверджувати, що у вищій школі не готують майбутніх учителів початкових класів до викладання в початкових класах літературного краєзнавства. Утім, частково ці питання розглядаються в курсі «Література для дітей». У процесі вивчення цієї дисципліни відводиться 1 лекція та 1 практичне заняття, які присвячено ознайомленню з письменниками Прикарпаття - авторами творів для дітей. Вивчаючи розвиток української літератури для дітей, студенти мають змогу ознайомитись із творчими надбаннями письменників Прикарпаття, зокрема із творами Марійки Підгірянки, Костянтини Малицької, Дмитра Павличка, Степана Пушика, Лесі Диркавець-Пилип'юк, Надії Дички, Віри Багірової, Ярослава Яроша, Степана Процюка, які адресовані дітям, відомі широкому колу читачів, оскільки виходили як окремими книжками, так і публікувались у періодичних виданняхУкраїни. 
Огляд цього матеріалу не тільки дає уявлення про тематичну та жанрову, стильову природу текстів для дітей, а й специфріку зображених художніх світів, зумовлену бойківським та гуцульським колоритом [5, с. 19-27].

Уроки літератури рідного краю мають свої особливості. По-перше, їх потрібно планувати, враховуючи специфіку літератури як виду мистецтва; по-друге, варто добирати літературні твори і мистецький матеріал високої літературно-естетичної вартості; по-третє, уміло поєднувати ознайомлення краєзнавчої літератури 3 використанням образотворчого мистецтва, музики, архітектури, історії, релігії, фрілософії свого краю тощо; почетверте, забезпечувати формування естетичних смаків, переконань, ідеалів школярів відповідно до народних традицій; по-п'яте, виробляти особистісне ставлення до художньої літератури рідного краю, щоб допомогти учневі самовиразитися, самоствердитися й усвідомити, що митці-земляки не тільки відображають своє сприйняття світу, а й передають енергію власного бачення життя з його добром і злом, красою і потворністю і цим допомагають дитині творити своє «Я» в єдності з природою, людством, нацією, рідним краєм [8, с.16].

Мета уроків літературного краєзнавства - «осягнення учнями глибинної сутності спадщини митців свого краю, космосу духу земляків, реалій дійсності, сприйняття й поціновування їхнього художнього набутку, плекання почуття гордості за творчих людей, славних краян» [6, с. 135]. На основі вивчення джерел [1-2; 5-10] виокремлюємо завдання уроків літератури рідного краю: поглиблювати відомості про життя і творчість митців певної місцевості (у нашому випадку Прикарпаття); розвивати інтерес до їхнього творчого доробку та спадщини; формувати в дітей історичну пам'ять, плекати природне почуття національної гордості; прищеплювати повагу до видатних людей рідного краю, їхнього внеску в національно-визвольну боротьбу, спонукати наслідувати їх у своєму житті; плекати працелюбність, милосердя, гуманне ставлення до людини, природи тощо; виробляти вміння бачити й цінувати красу й самобутність рідної землі; викликати в учнів щире прагнення захищати світлі набутки матеріального й духовного життя нації, оберігати й примножувати їх, продовжуючи традиції роду, родини, краю, тощо.

Отже, літературне краєзнавство - це важливе знаряддя патріотичного, морально-етичного виховання, дійовий засіб поглиблення знань з літератури і розвитку пізнавальних інтересів молодших школярів. Воно сприяє вихованню національної самосвідомості, зацікавленню учнів історією, культурою рідного краю, його фрольклорними традиціями та ін.

\section{ВИСНОВКИ ТА ПЕРСПЕКТИВИ ПОДАЛЬШИХ ДОСЛІДЖЕНЬ}

Значна роль у формуванні національно-мовної особистості належить початковій школі і формується переважно засобами рідної мови та літератури. Провідне місце в цьому процесі відведено літературному краєзнавству, яке формує духовний світ особистості, виховує загальнолюдські й національні цінності в учнів. Важливою державною справою літературне краєзнавство стає за сучасних умов розбудови української держави, коли йому належать відповідальні функції в ділянці формування національної самосвідомості, виховання національно-мовної особистості.

\section{СПИСОК ВИКОРИСТАНИХ ДЖЕРЕЛ}

[1] Гуняк М. Можливості літератури рідного краю. Українська мова та література. 2002. № 40. С. 3-4.

[2] Бугрій В. С. Краєзнавча робота як засіб розвитку пізнавальних можливостей учнів загальноосвітніх шкіл України. Педагогічний альманах: Збірник наукових праць. Херсон: РІПО, 2010. Випуск 7. С. 260-264.

[3] Енциклопедія сучасної України (ЕСУ). 2014. URL: http://esu.com.ua

[4] Концепція національно-патріотичноговиховання дітейі молоді. URL : mon.gov.ua/.../konczepcziya-naczionalno-patriotichnogo-vixovan...

[5] Круль Л. М., Т. Б. Качак. Дитяча література: методичні рекомендації до практичних занять. Івано-Франківськ, 2011.40 с.

[6] Лисенко А. В. Роль і місце літературного краєзнавства у процесі відродження національної школи. Збірник наукових статей «Літературне краєзнавство: проблеми, пошуки, перспективи». Полтава: ПДПУ, 2002. С. 131-138.

[7] Ляшенко Н.Г. Використання краєзнавчого матеріалу у школі I ступеня. Ржищів: 2013. 17 с.

[8] Самойленко Г. В. Краєзнавство культурно-мистецьке та літературне: навч. посібн. Ніжин: НдПУ, 2001. 150 с.

[9] Уроки літератури рідного краю. Українська література. URL : www.ukrlit.net/article/39.htm

[10] Шляхова В. Українознавчі засади сучасної мовної освіти. URL : http://www.ualogos.kiev.ua/fulltext.html?id=1826.

\section{REFERENCES (TRANSLATED AND TRANSLITERATED)}

[1] Hunyak M. Mozhlyvosti literatury ridnoho krayu (Possibilities of literature of native land). Ukrayins'ka mova ta literatura. 2002. № 40. S. 3-4. (in Ukrainian)

[2] Buhriy V. S. Krayeznavcha robota yak zasib rozvytku piznaval'nykh mozhlyvostey uchniv zahal'noosvitnikh shkil Ukrayiny (Local studies as a means of development of cognitive abilities of students of general education schools of Ukraine). Pedahohichnyy al'manakh: Zbirnyk naukovykh prats'. Kherson: RIPO, 2010. Vypusk 7. S. 260-264. (in Ukrainian)

[3] Entsyklopediya suchasnoyi Ukrayiny (ESU) (Encyclopedia of modern Ukraine). 2014. URL : http://esu.com.ua (in Ukrainian)

[4] Kontseptsiya natsional'no-patriotychnoho vykhovannya ditey i molodi (The concept of national patriotic education of children and young people). URL : mon.gov.ua/.../konczepcziya-naczionalno-patriotichnogo-vixovan... (in Ukrainian)

[5] Krul' L. M., Kachak T. B. Dytyachaliteratura : metodychni rekomendatsiyi do praktychnykh zanyat' (Children's literature: methodical recommendations for practical classes). Ivano-Frankivs'k, 2011. 40 s. (in Ukrainian)

[6] Lysenko A.V. Rol' i mistse literaturnoho krayeznavstva u protsesi vidrodzhennya natsional'noyi shkoly (The role and place of literary regional studies in the process of revival of the national school). Zbirnyk naukovykh statey «Literaturne krayeznavstvo: problemy, poshuky, perspektyvy». Poltava: PDPU, 2002. S. 131-138. (in Ukrainian)

[7] Lyashenko N.H. Vykorystannya krayeznavchoho materialu u shkoli I stupenya (Use of local history material at elementary school). Rzhyshchiv, 2013. 17 s. (in Ukrainian)

[8] Samoylenko H. V. Krayeznavstvo kul'turno-mystets'ke ta literaturne (Regional studies of cultural, artistic and literary): navch. posibn. Nizhyn: NDPU, 2001. $150 \mathrm{~s}$.

[9] Uroky literatury ridnoho krayu. Ukrayins'ka literatura (Lessons from the literature of the native land. Ukrainian literature). URL : www.ukrlit.net/article/39.htm (in Ukrainian)

[10] Shlyakhova V. Ukrayinoznavchi zasady suchasnoyi movnoyi osvity (Ukrainian-fundamentals of modern language education). URL : http://www.ualogos.kiev.ua/fulltext. (in Ukrainian)

Рецензент: Білавич Г.В., доктор педагогічних наук, професор, ДВНЗ «Прикарпатський національний університет імені Василя Стефраника» 